профілю підготовки фахівця [6, с. 58].

Під загальними умовами дослідник розуміє:

- загальну мету підготовки фахівця;

- зміст загальної підготовки;

- наявність певної системи підготовки;

- педагогічні принципи;

- загальні педагогічні форми і методи підготовки фахівців у ВНЗ;

- формування у майбутніх учителів нового педагогічного мислення;

- морально-психологічний клімат;

- матеріально-технічна база, ТЗН;

- наявність творчо працюючих фахівців.

До спеціальних педагогічних умов С. Руссков відносить необхідні і достатні умови, що забезпечують підготовку вчителя до професійно-творчої діяльності у виховання молодших школярів. Наприклад, власну мету і завдання; зміст, зумовлений власною метою і завданнями; урахування місцевих і регіональних особливостей при визначенні змісту підготовки; урахування «місцевих потреб» у фахівцях; використання нетрадиційних форм і методів підготовки; урахування мотиваційної спрямованості; наявність спеціальної матеріально-технічної бази (музей, періодична художня виставка, експонати тощо).

\title{
Література
}

1. Даль В. И. Толковый словарь живого великорусского языка / В. И. Даль. - М., 1955. 2. Педагогический энциклопедический словарь / гл. ред. Б. М. Бим-Бад. - М. : Большая Российская энциклопедия, 2003. 3. Селевко Г. К. Энциклопедия образовательных технологий: в 2 т. / Г. К. Селевко. - М. : НИИ школьных технологий, 2006. - Т. 2. - 816 с. 4. Теория воспитания. Лабораторно-практические занятия для студентов: [учеб. пособ.]/ под ред. И. А. Тютьковой. - М. : «РИО» Мособлупрполиграфиздата, 2000. - 173 с. $\quad$ 5. Ушинский К. Д. Избранные педагогические сочинения: в 2 т. / К. Д.Ушинський. - М., 1974. б. Харламов И. Ф. Педагогика: [учеб. пособ.] / И. Ф. Харламов. - М. : Высш. шк., 1999. - 512 с.

Олег Цись

\section{АНАЛІЗ СУЧАСНИХ ПІДХОДІВ ДО ФОРМУВАННЯ ПРОФЕСІЙНОЇ МОБІЛЬНОСТІ МАЙБУТНІХ ФАХІВЦІВ}

Цись О. О. Аналіз сучасних підходів до формування професійної мобільності майбутніх фахівців.

У статті автор розкриває різні підходи (системний, особистісно-орієнований, суб'єктно-діяльнісний) до формування професійної мобільності майбутніх фахівців. Викладені результати теоретичного аналізу науково-педагогічної літератури, пов'язаної з підходами до формуванням професійної мобільності майбутніх фахівців. Окреслено шляхи і напрями задля подальших досліджень.

Ключові слова: професійна мобільність, формування професійної мобільності, системний підхід, особистісно-орієнований підхід, суб'єктно-діяльнісний підхід.

Цысь О. А. Анализ современных подходов к формированию профессиональной мобильности будущих специалистов.

В статье автор раскрывает различные подходы (личностно-ориентирований, 
системный, субъектно-деятельностный) к формированию профессиональной мобильности будущих специалистов. Изложены результаты теоретического анализа научно-педагогической литературы связанной с подходами к формированием профессиональной мобильности будущих специалистов. Обозначенные пути и направления для дальнейших исследований.

Ключевые слова: профессиональная мобильность, системный подход, формирование профессиональной мобильности, личностно-ориентирований подход, субъектно-деятельностный подход.

Tsys O. A. The analysis of current approaches towards developing professional mobility of future specialists.

The article reveals different approaches (personality-oriented, system, subject and activity) to form professional mobility of future specialists. The author suggests results of theoretical analysis of scientific and educational literature connected with approaches towards developing professional mobility of future specialists. The areas for further researches are defined.

Key words: professional mobility, developing professional mobility, system approach, personality-oriented approach, subject and activity approach.

Професійна мобільність як складний соціальний феномен має суттєвий вплив на розвиток і функціонування різних галузей суспільства: соціальної, економічної, соціокультурної, професійної тощо. Дослідження цього феномену 3 позиції тільки одного підходу було б обмеженим і неповним. Тому, щоб науково обгрунтувати процес формування професійної мобільності у контексті нашого дослідження, буде доцільним розглянути основні наявні і пріоритетні підходи відповідно до цього процесу.

Нині проблема формування професійної мобільності вивчається вітчизняними й зарубіжними науковцями 3 позиції різних підходів: гуманістичного (Л. Амірова, 3. Багішаев), синергетичного (Є. Неділько, І. Нікуліна), суб'єктно-діяльнісного й особистісно-діяльнісного (Б. Ігошев, Т. Луданова, Е. Нікітіна), ресурсного (Т. Заславська, В. Радаєв, В. Чупров, О. Шкаратан), системного (В. Афанасьєв), структурно-функціонального (О. Конт, Г. Спенсер, Е. Дюркгейм), стратифікаційностатусного (П. Сорокін), компетентнісного (Л. Горюнова) та інших.

3-поміж підходів, які використовують дослідники, на сучасному етапі найбільш поширеними є системний, особистісно орієнтований, суб'єктно-діяльнісний.

Суть системного підходу полягає в тому, що об'єкт, який пізнається, розглядається як система того чи іншого рівня і маэ певну структуру та організацію.

У загальному розумінні система - це сукупність компонентів, які перебувають у тісних взаємозв’язках й утворюють певну цілісність, єдність. Поняття «цілісності» містить у собі надзвичайно важливий зміст. За своєю суттю цілісність - «це принципова незвідність властивостей системи до сукупності властивостей іiі складників, і непохідність із властивостей останніх цілого, залежність кожного елемента, властивості і відношення системи від його місця, функції тощо усередині цілого» [1, с. 584].

Саме на розкриття цілісності об'єкта і механізмів, що іiі забезпечують, на виявлення різноманітних типів зв'язків складного об'єкта i зведення їх до єдиної теоретичної картини орієнтує дослідження системний підхід.

Оскільки винятковою рисою системи $є$ те, що вона володіє новими, інтегративними якісними характеристиками, які не містяться в її складників, на якісну 
характеристику системи більшою мірою впливає ії структура, ніж склад компонентів. При цьому компонентом, або елементом системи, виступає мінімальна структуроутворювальна одиниця системи, що має межу подільності у їі кордонах, має функціональну і структурну специфічність, а також функціональну інтегративність.

Відповідно, щоб дослідити систему, як уважає В. Афанасьєв, необхідно виявити:

- іiі склад , тобто елементи, що ії утворюють;

- внутрішні зв'язки і зв'язки їі елементів із середовищем, характер цих зв'язків, їх вплив на цілісність і функціонування системи;

- структуру як єдність стійких взаємозв'язків між їі елементами;

- функції системи в цілому і функції кожного компонента, виявити дублюючі і «занепадні» функції ;

- інтегративні системні чинники (механізми), що забезпечують їі цілісність;

- історію (початок і джерело) їі виникнення, етапи та тенденції, спрямованість і перспективи розвитку;

- iï сутнісну, якісну специфіку, властиві їй інтегративні якості [2, с. 23].

Упровадження системного підходу в науковому пізнанні пов'язане 3 тим, що в багатьох науках виник новий тип наукових завдань, у яких центральними стають проблеми організації і функціонування складних об'єктів. У другій половині XX ст. аналогічні завдання почали виникати i в соціальній практиці: в соціальному управлінні замість визначальних раніше локальних, галузевих завдань і принципів провідну роль стали відігравати комплексні проблеми, що вимагали інтегрального підходу в розгляді їх різних аспектів (змістових, організаційних, функціональних тощо).

Виходячи $з$ того, що принцип системності під час дослідження об'єктів означає розгляд їх з позиції домінування цілого над складниками, системоутворювальних зв'язків між ними, їх ієрархії, організаційних структур, змістовою стороною принципу, на думку П. Атутова, є субординація цілей, зв'язків елементів і взаємозв'язку. Варто зазначити, що принцип системності пов'язаний із гносеологічними функціями, загальною методологією пізнання, ціннісними орієнтаціями в пізнанні, комплексним підходом у дослідженні. Ієрархія зв'язків, складників системи $\epsilon$ провідною ознакою реалізації принципу системності [4, с. 96].

Варто зазначити, що вище зазначені системні характеристики повною мірою властиві й педагогічній системі, яка, взаємодіючи з середовищем, може розглядатися як елемент вищої, стосовно іiі, більш широкої системи. Структура цієї системи $є$ такою, що іiї елементи мають стосовно неї властивості підсистем.

В основу системного підходу до професійної підготовки вчителя, на думку Р. Пріми, варто покласти розуміння системи навчально-виховного процесу як такого, що забезпечує цілісність взаємозв'язку між окремими його ланками (елементами) управління, навчання, виховання, інформаційна, методична [5, с. 61 -64]. Науковець зауважує що, суттєвим у дослідницькій позиції є також розгляд системного підходу у зв'язку із суспільними інституціями в суцільному освітньому середовищі. Якісною характеристикою взаємодії компонентів системи «людина - педагогічна діяльність» (професія), а отже, результатом впливу всіх механізмів освітнього середовища буде професійно підготовлений учитель.

Отже, незважаючи на те, що в теорії систем переконливо показано, що знання, отримане на основі системного підходу, володіє найбільшою силою, тим не менш, наявною $є$ обмеженість цього підходу, особливо під час вивчення надзвичайно складних природних, біологічних і соціальних об'єктів. Вона полягає в тому, що наші знання про ці «системи» загалом на сучасному етапі є надзвичайно обмеженими, а 
тому по суті досліджуються не власне системи, а їх структури. Якщо під системою розуміється все ціле 3 усіма об'єктами і зв'язками між ними, то під структурою певна схема стійких елементів цього цілого. Складність наявних і чинних на певному етапі розвитку елементів і зв'язків між ними фактично нівелюється, залишається лише те, що стійко зберігається в часі або легше піддається вивченню.

Суб'єктно-діяльнісний підхід досліджує професійну мобільність із психологічних позицій як характеристику соціального функціонування людини, тобто як якість соціального суб'єкта (індивіда), яка виявляється в його діяльності. Методологічною основою цього напрямку досліджень $є$ особистісно-діяльнісний підхід, що базується на таких фундаментальних положеннях:

- про єдність діяльності й особистості (К. Абульханова-Славська, Г. Акопов, А. Асмолов, В. Зінченко та ін.);

- про особистість як активного суб'єкта діяльності та взаємозв'язків зі світом (Л. Божович, Д. Леонтьєв та ін.);

- про творчий потенціал особистості та можливості їі реалізації у професійній діяльності (Є. Климов, Н. Нікандров та ін.);

- про багатовимірність простору розвитку особистості (С. Бондирева, В. Штейнберг та ін.)

На думку Л. Горюнової, професійна мобільність фахівця відповідно до особистісно-діяльнісного підходу виявляється в мотивованій і цілеспрямованій діяльності індивіда й активізується у «вузлових моментах» його професійножиттєвого шляху. Ступінь успішності діяльності залежить від реальних «стартових можливостей» фахівця i готовності 3 ними працювати. Ознаками професійної мобільності, з позиції окресленого підходу, є такі: здатність фахівця рефлексувати вихідний рівень свого професіоналізму, своїх можливостей, об'єктивно оцінювати ступінь змін, що відбулися у своїй особистості й діяльності, готовність фахівця до змін у життєдіяльності, ступінь активності, ефективне цілепокладання, передбачення результатів [6, с. 21].

Оскільки професійна мобільність виявляється як сукупність певних особистісних властивостей і якостей людини, вона також повинна вивчатися в педагогіці на основі особистісно орієнтованого та аксіологічного підходів, які формуються у вітчизняній освіті у процесі пошуку нової освітньої парадигми, покликаної змінити традиційну, «знаннєву» парадигму.

Особистісно орієнтований підхід, який $є$ найбільш безпосереднім виразом гуманістичної концепції у вітчизняній освіті, в сучасних умовах є як парадигмою становлення людини в демократичному суспільстві і визначає головний стратегічний напрямок розвитку системи освіти.

Як зазначає Е. Зеер, «з усією певністю можна констатувати, що особистісно орієнтоване навчання виникло у процесі педагогічного пошуку педагогів-новаторів, у практиці створення інноваційних навчальних закладів, варіативних навчальних планів, регіональних програм освіти» [7, с. 114]. Воно стало альтернативою традиційній когнітивній парадигмі освіти, в рамках якої мета навчання відображає соціальне замовлення на якість знань, умінь і навичок. Відповідно до цього вся організація навчання орієнтована на відображення в програмах, підручниках, методиках стану наукового знання і способів його засвоєнн, контроль характеру i якості виконуваних навчальних дій (розумових і практичних), а особистісні аспекти навчання, по суті, зводяться до формування пізнавальної мотивації і пізнавальних здібностей.

Тому, незважаючи на те, що в рамках когнітивно-орієнтованої парадигми 
присутній особистісний аспект, він не виходить на рівень цільових установок освіти. Характеризуючи особистісно орієнтований підхід до професійної підготовки майбутніх фахівців у контексті дослідження формування професійної мобільності спеціалістів технічного профілю засобами іноземної мови, Л. Меркулова зазначає що, особистісно орієнтований підхід впливає як на постановку цілей навчання іноземних мов, так i на постановку цілей формування компонентів професійної мобільності [8, с. 230].

Науковець підкреслює, що відповідно до особистісно орієнтованого підходу варто розрізняти рівні навченості: загальноосвітній і більш поглиблений профільний, орієнтований на обрану професію. Особистісно орієнтований підхід передбачає гнучкість у визначенні цілей, з урахованням індивідуальних особливостей та особистісних інтересів студентів, передбачаючи залучення учня до процесу визначення мети, вибір індивідуальної траєкторії навчання (вибір елективних курсів, профілю).

Стосовно змісту навчання особистісно орієнтований підхід, на думку автора, виявляється в таких основних напрямках:

- компонентний склад змісту навчання спрямований на діяльнісну компоненту, розвиток досвіду творчої діяльності й ціннісні орієнтації;

- націленість на розвиток учнів, у тому числі інтелектуальний, вимагає проблемної подачі матеріалу, що має знаходити відображення в підручниках основних «носіях» змісту навчання;

- під час відбору змісту важливо передбачити такі матеріали, які апелюють до особистого досвіду студентів, їх почуттям і емоціям, спонукають їх до порівнянь і зіставлень, висловом власної думки, що стимулює розвиток критичного мислення, ціннісних орієнтації.

Водночас Л. Меркулова зауважує, що ефективна підготовка сучасного фахівця можлива за умови дотримання низки психолого-педагогічних умов, що дозволяють реалізувати індивідуалізацію навчально-виховного процесу:

- розгляд активності студентів у якості основи задля вияву і розвитку важливих для майбутньої професійної діяльності індивідуальних особливостей і схильностей;

- забезпечення дидактичних засобів прояву і розвитку активності студентів на теоретичних і практичних заняттях (включення в ігрову, творчу діяльність тощо);

- підготовка викладачів до індивідуальної роботи зі студентами [8, с. 233].

У процесі реалізації особистісно орієнтованого підходу в навчанні, вихованні та формуванні компонентів професійної мобільності важливе місце займають взаємовідносини між суб'єктами освітнього процесу. В своїй роботі В. М'ясищев показав, що соціально-психологічні характеристики людей відрізняються один від одного ступенем усвідомлення своїх відносин до різних сторін дійсності, а також глибиною і правильністю розуміння причин, які ці відносини викликають. У одних 3 них це тенденція бачити ці причини тільки в самих собі, в інших - переважно в оточуючих, у третіх - в збігу обставин [9, с. 152].

Варто зауважити, що за особистісно орієнтованого підходу враховуються індивідуальні відмінності у ставленні студентів до навчальної та майбутньої професійної діяльності, які виражаються у вибірковому ставленні до тих чи інших навчальних предметів, неоднаковому ставленні до різних видів навчальної діяльності (самостійна робота, практичні та лабораторні заняття).

Досліджуючи підготовку професійно мобільних педагогів, Б. Ігошев зазначав, що методологічно особистісно орієнтована освіта засновується на визнанні у якості системоутворювального чинника особистості учня: його потреб, мотивів, цілей, 
здібностей, активності, інтелекту та інших індивідуально-психологічних особливостей. Це утворення передбачає, що у процесі навчання максимально враховуються статево-вікові, індивідуально-психологічні та статусні особливості учнів. Облік здійснюється через зміст освіти, варіативність освітніх програм, технології навчання, організацію навчально-просторового середовища. Принципово змінюється взаємодія учнів і педагогів - вони стають суб'єктами процесу навчання, а діяльність учіння, пізнавальна діяльність, стає в системі «учитель-учень» провідною [10, с. 95].

Водночас гуманістично орієнтована освіта досить складно піддається інструменталізації, зокрема, технологізації та стандартизації, що в умовах сучасного суспільства суттєво обмежує можливості іiі практичної реалізації. Ця проблема пов'язана $з$ тим, що, як справедливо зазначає Т. Дубовицька, «гуманістичне навчання становить не якийсь метод, а сукупність цінностей, особливу педагогічну філософію, нерозривно пов'язану з особистісним способом буття людини» [11, с. 285]. Оскільки головним результатом такої освіти повинні стати не знання, уміння і навички, якими оволодіває учень, а його особистість, необхідно в чітких параметрах визначити, яка особистість може забезпечити прогресивний розвиток суспільства і що для цього може зробити суспільство, а це надзвичайно важке завдання.

Проте особистісно орієнтований підхід здійснює значний вплив на розвиток освіти, зумовлюючи пошук способів і шляхів позитивного, формуючого впливу у процесі освіти на особистість учня, забезпечення умов для його розвитку. У професійній освіті він реалізується, перш за все, як орієнтація на професійний розвиток учня, формування певних особистісно-професійних якостей і застосовується поряд із такими методологічними підходами, як системний, суб'єктний тощо.

Отже, міждисциплінарний характер професійної мобільності, як соціального феномену, що виявляє вплив на розвиток як суспільства в цілому, так і його різних галузей, зумовлює необхідність застосування у процесі його дослідження різних підходів, які поєднують методологію різних наук. Тільки такий цілісний, комплексний підхід дозволить уникнути односторонності в розумінні професійної мобільності як науково-педагогічного феномену.

Подальшим етапом нашого дослідження $є$ вивчення й аналіз змісту професійної підготовки майбутніх учителів технологій у контексті формування їхньої професійної мобільності.

\section{Література}

1. Философский энциклопедический словарь / 2-е изд. - М. : Сов. энциклопедия, 1989. - 815 с. 2. Афанасьев В. Г. Моделирование как метод исследования социальных систем / В. Г. Афанасьев // Системные исследования. - М., 1982. - С. 26-46. 3. Гершунский Б. С. Философия образования для XXI века. (В поисках практикоориентированных образовательных концепций) / Б. С. Гершунский. - М. : Изд-во «Совершенство», 1998. - 608 с. 4. Методологические проблемы развития педагогической науки / под ред. П. Р. Атутова, М. Н. Скаткина, Я. С. Турбовского. М. : Педагогика, 1985. - 240 с. 5. Пріма Р. М. Формування професійної мобільності майбутнього вчителя: методологічні підходи / Р. М. Пріма // Збірник наукових праць. - 2011. - С. 61-65. 6. Горюнова Л. В. Профессиональная мобильность специалиста как проблема развивающегося образования России: автореф. дис. на соискание ученой степени д-ра пед. наук / Л. В. Горюнова. - Ростов н/Д, 2006. - 44 с. 7. Зеер Э. Ф. Становление личностно-ориентированного образования / Э. Ф. Зеер // Образование и наука: известия Уральского научно-образовательного центра РАО.1999. - № 1. - С. 112-122. 8. Меркулова Л. П. Формирование профессиональной 
мобильности специалистов технического профиля средствами иностранного языка: дис. ... д-ра. пед. наук: 13.00.08 / Л. П. Меркулова. - Самара, 2008. - 454 с. 9. Мясищев В. Н. Проблема отношений человека и eе место в психологии / В. Н. Мясищев // Вопросы психологии. - 1967. - № 5. - С. 142-154. 10. Игошев Б. М. Системно-интегративная организация подготовки профессионально мобильных педагогов: дис. ... д-ра. пед. наук: 13.00.08 / Б. М. Игошев. - М., 2008. - 394 с. 11. Дубовицкая Т. Д. Гуманистическая теория и практика образования / Т. Д. Дубовицкая // Педагогическая наука и ее методология в контексте современности: сб. науч. ст. - М., 2001. - С. 281-286.

\section{ФОРМУВАННЯ МОВНОЇ КОМПЕТЕНТНОСТІ МАЙБУТНІХ УЧИТЕЛІВ ПОЧАТКОВИХ КЛАСІВ У ВНЗ І-І РІВНЯ АКРЕДИТАЦЇ У ПРОЦЕСІ ФАХОВОЇ ПІДГОТОВКИ}

Шаранда В. С. Формування мовної компетентності майбутніх учителів початкових класів у ВНЗ І-ІІ рівня акредитації у процесі фахової підготовки.

Статтю присвячено дослідженню педагогічних засад формування мовної компетентності майбутніх учителів початкових класів у ВНЗ I-II рівнів акредитації у процесі фахової підготовки. Авторка аналізує теоретичні основи формування, рівні розвитку і зміст мовної компетентності майбутніх учителів, а також представляє методику формування мовної компетентності майбутніх учителів початкових класів у процесі фахової підготовки.

Ключові слова: мовна компетентність, майбутні вчителі, фахова підготовка, педагогічні засади.

Шаранда В. Е. Формирование языковой компетентности будущих учителей начальных классов в ВУЗе I-II уровня аккредитации в процессе профессиональной подготовки.

Статья посвящена исследованию педагогических основ формирования языковой компетентности будущих учителей начальных классов в вузах I-II уровней аккредитации в процессе профессиональной подготовки. Автор анализирует теоретические основы формирования, уровни развития и содержание языковой компетентности будущих учителей, а также представляет методику формирования языковой компетентности будущих учителей начальных классов в процессе профессиональной подготовки.

Ключевые слова: языковая компетентность, будущие учителя, профессиональная подготовка, педагогические основы.

Sharanda V. Ye. Forming primary school teachers' linguistic competence at higher schools of the first and second level of accreditation in the process of professional training.

The article is devoted to the pedagogical fundamentals of forming primary school teachers' linguistic competence at higher schools of the first and second level of accreditation in the process of professional training. The author analyzes the concept of linguistic competence, the theoretical fundamentals of its formation, and the levels of its development. The author also presents the technique of forming primary school teachers' linguistic competence in the process of professional training.

Key words: linguistic competence, future teachers, professional training, pedagogical fundamentals. 